\title{
Effect of Environmental Penalties on the Cost of Equity - The Role of Corporate Environmental Disclosures
}

\author{
Xiangan Ding ${ }^{1 *}$, Mohsin Shahzad ${ }^{2 * *}$ \\ ${ }^{1}$ School of Government, Liaoning Normal University, Dalian, China \\ ${ }^{2}$ School of Economics and Management, Dalian University of Technology, Dalian, China
}

Received: 3 June 2021

Accepted: 30 August 2021

\begin{abstract}
Environmental administrative penalty is a powerful way for the government to realize environmental pollution control. When a firm is subjected to an environmental administrative penalty, how the penalty affects its equity cost is a hot issue in academia and industry. Using the ordinary least square method and the Bootstrap method, it is found that environmental penalties significantly increase corporate equity costs in the following year through their disclosure increments; the disclosure increment plays a mediating role in the positive effect. It is also found that the reduced negative information disclosures can increase the effect, while the increased positive information can reduce the effect. These findings help us understand environmental management's significance to a firm's financing sustainability and have practical enlightenment on environmental management and environmental pollution control.
\end{abstract}

Keywords: environmental administrative penalty, environmental information disclosure, the cost of equity, environmental pollution control

\section{Introduction}

Severe environmental pollution brought by highspeed economic growth in China caused great attention at home. How to control environmental pollution has been the focus of current policy discussions. There is a consensus that the lack of information transparency and public supervision is bound to be the hotbed of the spread of environmental pollution in enterprises. Therefore, environmental information disclosure is

e-mail: dingxa@foxmail.com

**e-mail: mohsin@dlut.edu.cn widely regarded as an effective tool to achieve pollution control.

Like the environmental information disclosure (EID), environmental administrative penalty is also a powerful tool for the government to realize environmental pollution control. China's new Environmental Protection Law was implemented on January 1, 2015. The revised law has strengthened the law enforcement power of the environmental protection departments and the local government. The number of environmental-illegal cases investigated by the national environmental protection departments according to law has increased substantially.

The problems exposed in the process of environmental information disclosure of penalized 
companies are increasingly concerned by society. Some listed companies subjected to environmental administrative penalties reportedly avoid disclosing important issues, make a false statement, or even do not disclose environmental information $[1,2]$. These environmental disclosure manipulations have a bad impact on corporate financing and infringe on investors' interests. As such, we question that what is the effect of the environmental administrative penalty on corporate equity financing and whether the penalty affects equity cost through environmental disclosures.

Previous studies provide incomplete answers to these questions. Researches support that non-financial disclosure assumes particular importance [3-6]. Some found that corporate environmental disclosure is negatively correlated with the cost of equity (COE) [7-11]. Others confirmed the negative relation between environmental-related disclosure and COE [3, 1219]. However, Fonseka et al. (2019) found that the relationship between environmental disclosure and COE varies in different industries, which is positive in some industries and negative in others. Shad et al. (2020) found that environmental sustainability reporting reduces only the cost of debt but does not reduce the cost of equity for Malaysian companies. Dahiya and Singh (2020) found that investors in India do not treat CSR as a value-augmenting factor; thus, manufacturing companies disclosing CSR bear a higher COE. To explain it, Clarkson et al. (2013) argued that if stakeholders are more aware of the company's environmental-related performance, and environmental disclosures cannot provide investors with incremental information, then they will nIn China, many listed companies' annual environmental reports change little in different years, except for specific matters and figures changes, the expression of language is barely adjusted, which can even be deemed a "cloning report". We considered that the truly changing part of EID in the adjacent two years (EID increment) can provide additional information for demanders and is more valuable to equity investors.

Environmental administrative penalties refer to the administrative sanctions imposed by the Chinese local government on the firm that have committed environmental violations. After being penalized by environmental administrations, the quality of EID of these penalized companies will be reduced [1]. Moreover, environmental issues can affect COE [24, 25]. So, how environmental administrative penalty affects the cost of equity? Does environmental administrative penalty affect the cost of equity through the disclosure increment? These problems have not been solved in the existing literature, and are the focus of our study.

By using samples taken from Chinese listed companies in the manufacturing industry, this study aims to reveal the effect of environmental administrative penalties on the cost of equity, as well as the mediating role of EID increments. The contributions of this paper are mainly reflected in the following aspects. First, although several studies found that corporate financing is affected by punishment from securities regulators, corporate crime, corporate fraud, etc [26-29], less consideration has been given to how the environmental penalty affects COE. We verified the hypothesis that environmental penalties increase the cost of equity in the following year. It helps to identify the effectiveness and consequence of environmental penalties from the perspective of equity financing. Second, this paper reveals the EID increments' mediating role in the relationship between environmental penalty and COE for the first time. Besides, information nature plays different roles in the effect. These findings not only enrich the cognition of the role of environmental disclosure in the existing literature but also have strong practical enlightenment to the practice of corporate environmental management and government environmental regulation.

The paper is structured as follows. Section 2 presents the material and methods, including theoretical foundations, hypotheses development, and empirical research designs. Section 3 presents results and discussion. Section 4 is the conclusion.

\section{Material and Methods}

\section{Theoretical Foundations and Hypotheses Development}

Asset Pricing Theory attempts to explain the price or value of assets paid in the future under uncertain conditions, where assets usually refer to financial instruments, and the price refers to the price when the market is in equilibrium. In a deterministic market, an asset's current price can be directly discounted by its future earnings with a risk-free return rate. However, in reality, capital markets are filled with considerable uncertainty, creating risks. Therefore, asset pricing must consider the investor's attitude towards risks and the additional reward given to investors to compensate for the risks they bear.

The risk premium is one of the core concepts of financial economics, which means that investors require higher investment returns to compensate for the uncertainty, and the compensation is the risk premium. Equity capital is also a kind of risky asset because the return of equity capital has great uncertainty. Fisher and Hall (1969) found that rational man is risk-averse; for low risk, the required return is lower; for high risk, the required return is relatively high. Following common sense, when facing high risk, equity investors will raise the minimum return rate of the equity capital, and the equity cost will increase; when facing lower risk, the required return rate will be lower, and the $\mathrm{COE}$ will be reduced.

Risk is the part of the uncertainty that can be quantified. Environmental risk refers to the potential that inaccurate or incomplete environmental information 
may be disseminated to those considering an investment in the firm. Two common forms of investment are the purchase of bonds or the purchase of stocks. Some researches provide evidence that a decrease in environmental risk can lower the cost of equity capital. For example, Sharfman and Fernando (2008) found that firms can reduce their equity capital cost by improving their environmental risk management. Berry-Stölzle and $\mathrm{Xu}$ (2018) considered that risk management reduces the probability that a firm has to raise expensive external financing, thus reducing its expected cost of capital. Ahmed et al. (2019) found that firms with social and environmental practices have lower risk and cost of equity capital.

Corporate capital providers generally incorporate the firm's environmental risk or carbon risk into their capital allocation decisions or credit management processes [33-35]. Jung et al. (2018) considered that since a firm's exposure to carbon risk increases the uncertainty of its future cash flows, it likely influences default risk and leads the lenders to integrate carbon risk into their overall risk assessment. Besides, some researches indicate that environmental concerns or events may impact COE [24, 25]. For example, Chava (2014) found that investors demand significantly higher expected returns on stocks than firms without environmental concerns.

According to the above literature, investors usually increase the required return when faced with environmental risks. Furthermore, adverse environmental events or environmental concerns will increase future environmental risk and operating risk. If equity investors perceive higher environmental and economic risks brought by environmental penalties, then they will require a higher return on equity capital.

We propose the following hypothesis 1: Environmental administrative penalty has a positive impact on the cost of equity.

Some researchers have proven a correlation between COE and corporate environmental disclosure, CSR disclosure, and voluntary carbon disclosure [8-10, 12, $16,34]$. On the interpretation of how environmental disclosure is related to $\mathrm{COE}$, four kinds of views are generalized as follows. First, environmental disclosure reduces the investment risk perceived by investors, bringing a decrease in the required return on investment. Second, environmental disclosure improves stock demand and liquidity, thus reducing COE $[10,13,37]$. Third, high-quality environmental disclosure improves the accuracy of analysts' earnings forecasts, which reduces the cost of equity financing by reducing information risk [38]. Forth, firms with higher COE in the previous year tend to start disclosing CSR activities in the current year, with the consequence that its COE decreases [3, 7]. The above researches imply that investors attach importance to the environmental information disclosed in the company's annual report in the investment decision, so the environmental disclosure can reduce its COE.
The increment of EID is the variation of EID in adjacent years. When subjected to an environmental penalty, the companies' manipulation of disclosures will affect the quality of EID [1, 2]. Under the penalty, whether the increment of EID can reduce the COE of a company depends on whether the equity investor can identify the increment of the company's disclosure. The following studies provide evidence that equity investors can identify incremental disclosures. Healy et al. (1999) found that the share price of firms that increased environmental disclosure rises significantly in the same period, and this rise was not related to the company's earnings performance in the current period. Dhaliwal et al. (2011) found that firms with higher COE in the previous year tend to disclose CSR information from the current year, with the consequence that its $\mathrm{COE}$ also decreased. Raimo et al. (2020) found that increased levels of ESG disclosure are linked to improved access to financial resources for firms. Therefore, we suppose that the increment of EID of penalized companies will be identified by equity investors and used for decisionmaking.

When the increment of EID is negative under the environmental penalty, it shows that the penalty intensifies the information asymmetry between the management and investors. It increases the investment risk perceived by equity investors. Then, equity investors will increase the minimum of the required return on investment, which will increase the COE of the company. Whereas, when the increment of EID is positive, it increases the amount of information that equity investors can refer to when making decisions, reduces the degree of information asymmetry, and the investment risk perceived by investors. Then, equity investors will reduce the required return on investment, which will reduce the COE. Based on the above analysis, we argued that the positive increments of EID might reduce the positive effect between environmental penalties and COE, while the negative increments of EID are more likely to increase such an effect.

Therefore, hypothesis 2 is proposed: Environmental administrative penalty affects the cost of equity through the mediating role of incremental environmental information disclosure.

\section{Empirical Research Designs}

We performed the following design to test the two hypotheses: collecting samples and data, determining the variables and measuring them, and building metrological models for testing the mediating effect.

\section{Sample and Data}

The investigated companies are all manufacturing firms in Stock markets at Shanghai and Shenzhen stock exchanges in China. Manufacturing was chosen because it produces more waste pollution than other industries, has a higher environmental impact. 
In recent years, China's environmental protection authorities have increased environmental law enforcement efforts. The central government's emphasis on environmental protection at the legislative level has led to a significant increase in environmental penalty cases between 2015 and 2017. As such, more official data on the environmental violations of listed firms can be obtained. Besides, policy changes may have an impact on EID [40, 41]. To avoid changes in environmental regulations that may harm the findings, so we adopted 2015 as the starting year. We started collecting data in early 2019. At that time, the latest data available to us was in the fiscal year 2017.

We derived Data on EID from CSR reports and environmental reports disclosed on listed companies' official websites. Data on environmental administrative penalties are from the Institute of Public \& Environmental Affairs database. We derived financial data from the CSMAR database. After data collection, we found that 334 manufacturing listed companies have disclosed environmental information since 2015. We excluded the companies that lack relevant data and got 316 samples.

\section{Variables and Measurement}

COE refers to the cost that the company needs to pay to obtain equity capital, and it is also the minimum return on capital required by shareholders. Botosan et al. (2011) suggested that the modified PEG measure (MPEG) is the best, for measures employing analyst forecasts. Thus, we focus on MPEG as our primary method to calculate COE. Following Easton (2004) and consistent with Botosan et al. (2011) and Clarkson et al. (2013), we measure COE by MPEG as follows.

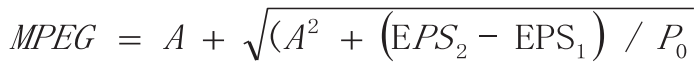

...where $\mathrm{A}=\mathrm{dps} / 2 \mathrm{P}_{0}, \mathrm{P}_{0}$ is the price per share, $\mathrm{dps}_{1}$ is the current year dividends, and $\mathrm{EPS}_{1}$ and $\mathrm{EPS}_{2}$ are one- and two-period ahead analysts' forecast of earnings per share.

This paper takes the increment of EID level $(\Delta E I D)$ as a mediator variable. EID level is measured first, and then the increment of EID level $(\Delta \mathrm{EID})$ is calculated. Content analysis is the most authoritative and widely recognized method to measure the EID level. The EID level is identified according to the content and degree of disclosure [44]. According to the studies of Meng et al. (2014), we determine the measurement contents of EID level. As shown in Table 1 , we set a total of seven categories. These categories reflect the realistic regulatory background of Chinese corporate environmental disclosure and reflect the regulations of the Chinese Ministry of Environmental Protection [2]. Among the categories, pollution control and environmental compliance, significant environmental impacts, events, and risk management are the information categories that the Ministry of Environmental Protection requires the listed companies in the heavy pollution industry to disclose, most of which belong to negative (hard) information. Therefore, this paper divides the quantification of EID into negative (hard) EID and positive (soft) EID. The level of positive EID (PEID) and negative EID (NEID) are quantified, respectively. The seven categories contain 43 items, which are shown in Table 1.

The content analysis measures the degree of disclosure by assigning each measurement item from 0 to 3. Quantified disclosure values 3, the specific but not quantified values 2 , simple description values 1 , and no description values $0[45,46]$. In this paper, each assignment of different measurement items is summed and then divided by the full score of all measurement items; the value of the annual EID is obtained. Next, the EID value in the adjacent two years is subtracted, and finally, the increment of EID is obtained.

The explanatory variable (PENALTY) is a dummy variable. If a company is subject to an environmental penalty, the value is 1 ; otherwise, the value is 0 .

This paper refers to the relevant literature to select control variables $[7,8,10]$. Considering the impacts of enterprise size, financial situation, profitability, development ability, operating ability, and other factors on the COE, we select asset size (SIZE), asset-liability ratio (LEV), return on total assets (ROA), growth of operating income (GROW), turnover of total capital (TURN) and book-to-market ratio (BM) as control variables.

Besides, the Beta coefficient can reflect the systemic risk of stock and the stock price fluctuation, which is an essential factor affecting COE. Hence, this paper sets it as a control variable. Environmental performance is also an essential factor affecting $\operatorname{COE}[9,23,45]$. Meng et al. (2014) designed a method to rank the environmental performance in three categories: poor, mixed, and good. We adopt this method and set two dummy variables, namely GEP and PEP. Descriptions of variables are described in Table 2 below.

Referring to the studies of Dhaliwal et al. (2011) and Edwards et al. (2016), this paper takes the change rate of $\mathrm{COE}$ as the explained variable. The variable design using the rate of change is based on two reasons. On the one hand, the design of using a change rate can better reflect the effect of the environmental penalty on $\mathrm{COE}$ and is more in line with the theoretical expectation of this study. On the other hand, it can effectively avoid metrological problems caused by the omission of relevant variables, and endogenous problem of the model to a certain extent $[7,47]$. So, the use of firstorder difference as a dependent variable is better than using the level of the variable.

\section{Models for Testing the Mediating Effect}

Sobel method and the Bootstrap method are the two commonly used methods to test the interaction items. 
Table 1. Measurement items of environmental information.

\begin{tabular}{|c|c|}
\hline Category & Items \\
\hline $\begin{array}{l}\text { Environmental values, } \\
\text { policies, and organization }\end{array}$ & $\begin{array}{l}\text { 1. Environmental values 2. Environmental protection policies and objectives } 3 \text {. Relevant } \\
\text { environmental organizations }\end{array}$ \\
\hline $\begin{array}{l}\text { Environmental management } \\
\text { system and initiative }\end{array}$ & $\begin{array}{l}\text { 1. Environmental certifications } 2 \text {. Voluntary cleaner production. } 3 \text {. Education and training } 4 \text {. Working } \\
\text { environment and plant greening } 5 \text {. Environmental information exchange } 6 \text {. Environmental accounting } \\
\text { 7. Environmental conservation projects } 8 \text {. Honors } 9 \text {. Third-party environmental audit }\end{array}$ \\
\hline $\begin{array}{l}\text { Environmental technology, } \\
\text { investment, and expenditure }\end{array}$ & $\begin{array}{l}\text { 1. R\&D of environmental technology 2. Waste treatment and technology 3. Construction } \\
\text { of environmental protection facilities } 4 \text {. Environmental loans or environmental investments } \\
\text { 5. Environmental-related grants and subsidies, etc. } 6 \text {. Recurrent expenditure }\end{array}$ \\
\hline $\begin{array}{l}\text { Resource consumption and } \\
\text { environmental performance }\end{array}$ & $\begin{array}{l}\text { 1. Total resource consumption 2. Total pollution discharge 3. Resource consumption, etc. } \\
\text { 4. Wastewater, emissions of major pollutants, etc. } 5 \text {. Environmental benefits. } 6 \text {. Social benefits } \\
\text { of reducing emissions }\end{array}$ \\
\hline $\begin{array}{l}\text { Environmental protection } \\
\text { and public welfare activities }\end{array}$ & 1. Environmental-related activities 2. Potential environmental impacts 3 . Others \\
\hline $\begin{array}{l}\text { Environmental compliance } \\
\text { and pollution control }\end{array}$ & $\begin{array}{l}\text { 1. Discharge of pollution up to standard 2. Emission reduction tasks } 3 \text {. Implementation of the "three } \\
\text { simultaneous" system } 4 \text {. Status of sewage charges } 5 \text {. Legal disposal of industrial solid and hazardous } \\
\text { wastes } 6 \text {. Applications for discharge permit } 7 \text {. Noise condition } 8 \text {. Environmental impact assessment }\end{array}$ \\
\hline $\begin{array}{l}\text { Significant environmental } \\
\text { impacts, events, and risk } \\
\text { management }\end{array}$ & $\begin{array}{l}\text { 1. Environmental violation and contamination in accident } 2 \text {. The environmental risk management } \\
\text { system } 3 \text {. Construction projects with significant environmental impact } 4 \text {. In the list of serious pollu- } \\
\text { tion enterprises } 5 \text {. Major risk sources } 6 \text {. Resident complaint } 7 \text {. The impact of environmental laws and } \\
\text { regulations on firm's operation } 8 \text {. An emergency plan for environmental emergencies }\end{array}$ \\
\hline
\end{tabular}

The confidence interval estimated by the Bootstrap method is more accurate and has higher test power than that estimated by the Sobel method [48, 49]. Hence, this paper uses the Bootstrap method to test interaction terms.

This paper uses the PROCESS plug-in of SPSS. 24 to test the mediating effect. The process of testing is divided into two parts. The first part is to test the main effect of the penalty on COE to verify hypothesis 1 .
The second part is to test the mediating effect of the EID increment, which is to verify hypothesis 2 . We employ the following models:

$$
\begin{gathered}
\triangle E I D=\beta_{0}+\beta_{1} \text { PENALTY }_{\mathrm{t}}+\beta_{\mathrm{i}} \text { Control } \\
+\sum \text { INDUSTRY }+\sum \text { YEAR }+\varepsilon
\end{gathered}
$$

\begin{tabular}{|c|c|c|c|}
\hline Category & Variables & Symbols & Descriptions \\
\hline Explained variable & Cost of equity & $\triangle \% C O E$ & Estimated by MPEG model \\
\hline Explanatory variable & Environmental administrative penalty & PENALTY & Dummy variable, if penalized, value 1 ; otherwise 0 . \\
\hline Mediator variable & EID increment & $\triangle E I D$ & Difference between values of EID in adjacent years \\
\hline \multirow{9}{*}{ Control variables } & Firm size & SIZE & Natural logarithm of the total assets \\
\hline & Asset-liability ratio & $L E V$ & Total liability/total asset \\
\hline & Book-to-market ratio & $B M$ & $\begin{array}{c}\text { Total assets at the end of year/(market value of } \\
\text { equity + market value of debt) }\end{array}$ \\
\hline & Return on total assets & $R O A$ & Net profit/total assets at the end of the year \\
\hline & Growth of operating income & GROW & $\begin{array}{l}\text { (Current operating profit - last year operating profit)/ } \\
\text { last year operating profit }\end{array}$ \\
\hline & Systematic risk & BETA & $\beta$ coefficient \\
\hline & Turnover of total capital & TURN & Turnover of total capital \\
\hline & \multirow{2}{*}{ Environmental performance } & GEP & $\begin{array}{c}\text { Dummy variable, if good environmental } \\
\text { performance, value } 1 \text {; otherwise } 0 .\end{array}$ \\
\hline & & $P E P$ & $\begin{array}{l}\text { Dummy variable, if poor environmental } \\
\text { performance, value } 1 \text {; otherwise } 0 .\end{array}$ \\
\hline
\end{tabular}

Table 2. Description of main variables. 


$$
\begin{aligned}
& \triangle \% C O E_{\mathrm{i}, \mathrm{t}+1}=\alpha_{0}+\alpha_{1} \text { PENALTY }_{\mathrm{t}}+\alpha_{\mathrm{i}} \text { Control } \\
& +\sum \text { INDUSTRY }+\sum \text { YEAR }+\varepsilon \\
& \Delta \% \text { COE }_{\mathrm{i}, \mathrm{t}+1}=\gamma_{0}+\gamma_{1} \text { PENALTY }_{\mathrm{t}}+\gamma_{2} \Delta E I D \\
& +\gamma_{\mathrm{i}} \text { Control }+\sum \text { INDUSTRY }+\sum \text { YEAR }+\varepsilon
\end{aligned}
$$

\section{Results and Discussion}

\section{Mediating Effect Test}

We test the mediating effect by using the Bootstrap method. The Bootstrap samples are set to be 5000, and the confidence interval is $95 \%$. As shown in Table 3 , in the total effect model, the variable PENALTY $\left(\alpha_{1}=0.269\right)$ and explained variable $\triangle \% C O E$ are significantly positive correlative, which verifies the hypothesis that environmental administrative penalty has a positive impact on $\mathrm{COE}$ in the following year.

The coefficient PENALTY $\left(\beta_{1}=-0.244\right)$ is significantly negative, indicating that the environmental administrative penalty is negatively correlated with EID. In regression (3), the $\triangle E I D$ coefficient $\left(\gamma_{2}=-0.176\right)$ is significantly negative, and the PENALTY coefficient $\left(\gamma_{1}=0.226\right)$ is significantly positive. The coefficient $\beta_{1} \gamma_{2}$ is the same sign as the coefficient $\gamma_{1}$. The test result of the mediating effect does not contain 0 at $95 \%$ confidence intervals, which indicates that the mediating effect of the increment of EID is significant. The mediating effect's value is 0.043 . These results verify hypothesis 2: the environmental administrative penalty has a positive impact on $\mathrm{COE}$ in the following year through the mediating effect of the EID increment.

We also distinguished environmental information's nature and then measured it from negative, sensitive (hard) information and positive (soft) information aspects. In this paper, the mediating effect of the negative information increment ( $\triangle$ NEID) and the positive EID increment $(\triangle \mathrm{PEID})$ are tested, respectively.

Table 4 shows the results of the mediating effect test on the PEID increment. The coefficient of PENALTY $\left(\beta_{1}=0.110\right)$ is positive, indicating that the penalty has a positive impact on PEID. The coefficient $\beta_{1} \gamma_{2}(-0.019)$ has the opposite sign as the coefficient $\gamma_{1}$, and the test result of the mediating effect does not contain 0 , which indicates that the mediating effect of the PEID increment is significant.

Table 5 shows the results of the mediating effect test on the NEID increment. The coefficient of PENALTY $\left(\beta_{1}=-0.22\right)$ is significantly negative. In regression

\begin{tabular}{|c|c|c|c|}
\hline Variables & $\triangle E I D$ & $\Delta \% C O E_{i, t+1}$ & $\Delta \% C O E_{i, t+1}$ \\
\hline Constant & $-0.150(-1.13)$ & $-1.159 * * *(-3.94)$ & $-1.186 * *(-2.03)$ \\
\hline PENALTY & $-0.244 * * *(-10.09)$ & $0.269 * * *(5.01)$ & $0.226^{* * *}(4.01)$ \\
\hline$\triangle E I D$ & & & $-0.176 * * *(-3.25)$ \\
\hline SIZE & $0.006(0.98)$ & $0.048 * * *(3.45)$ & $0.049^{* * *}(3.54)$ \\
\hline$L E V$ & $-0.038(-0.87)$ & $-0.133(-1.37)$ & $-0.140(-1.45)$ \\
\hline$R O A$ & $0.154(1.34)$ & $0.113(0.45)$ & $0.140(0.55)$ \\
\hline GROW & $0.00(-0.65)$ & $0.000(0.31)$ & $0.00(0.30)$ \\
\hline BETA & $0.043(3.26)$ & $0.075 * * *(4.53)$ & $0.082 * * *(2.78)$ \\
\hline$T U R N$ & $-0.01(-0.89)$ & $-0.023(-0.94)$ & $-0.025(-1.01)$ \\
\hline$B M$ & $0.001(0.14)$ & $0.002(0.48)$ & $0.007(0.37)$ \\
\hline GEP & $0.009 *(1.99)$ & $-0.022 * *(-2.37)$ & $-0.024 * *(-2.44)$ \\
\hline$P E P$ & $0.055(1.61)$ & $0.062 * *(2.69)$ & $0.072 * *(2.71)$ \\
\hline INDUS & YES & YES & YES \\
\hline$Y E A R$ & YES & YES & YES \\
\hline $\operatorname{Adj}-R^{2}$ & 0.068 & 0.156 & 0.167 \\
\hline F-value & $4.53 * * *$ & $9.83 * * *$ & $10.56^{* * *}$ \\
\hline Mediating Effect & Boot SE & Boot LLCI & Boot ULCI \\
\hline 0.043 & 0.018 & 0.015 & 0.085 \\
\hline
\end{tabular}
(3), the coefficient $\beta_{1} \gamma_{2}(0.062)$ has the same sign as the coefficient $\gamma_{1}$, and the confidence interval does not

Table 3. Test results of the mediating role of the EID increment.

Notes: ${ }^{*} \mathrm{p}<0.1,{ }^{* *} \mathrm{p}<0.05,{ }^{* * *} \mathrm{p}<0.01$. 
Table 4. Test results of the mediating role of the PEID increment.

\begin{tabular}{|c|c|c|c|}
\hline Variables & $\triangle P E I D$ & $\Delta \% C O E_{i, t+1}$ & $\Delta \% C O E_{i, t+1}$ \\
\hline Constant & $-0.018(-1.32)$ & $-1.159 * * *(-3.94)$ & $-1.152 * * *(-3.90)$ \\
\hline PENALTY & $0.110 * * *(7.08)$ & $0.269^{* * *}(5.01)$ & $0.262 * * *(4.75)$ \\
\hline$\triangle P E I D$ & & & $-0.172 * *(-2.65)$ \\
\hline SIZE & $-0.003(-1.46)$ & $0.048^{* * *}(3.45)$ & $0.052 * * *(4.75)$ \\
\hline$L E V$ & $-0.022(-1.02)$ & $-0.133(-1.37)$ & $-0.132(-1.36)$ \\
\hline$R O A$ & $0.075(0.43)$ & $0.113(0.45)$ & $0.111(0.44)$ \\
\hline GROW & $0.000 * * *(-2.80)$ & $0.000(0.31)$ & $0.00(0.37)$ \\
\hline BETA & $0.022(0.14)$ & $0.075 * * *(4.53)$ & $0.075^{* * *}(5.58)$ \\
\hline TURN & $-0.011(-1.10)$ & $-0.023(-0.94)$ & $-0.024(-0.96)$ \\
\hline$B M$ & $0.001(0.96)$ & $0.002(0.48)$ & $0.007(0.39)$ \\
\hline GEP & $0.003 * *(2.29)$ & $-0.022 * *(-2.37)$ & $-0.021 * *(-2.75)$ \\
\hline$P E P$ & $-0.004 *(-1.72)$ & $0.062 * *(2.69)$ & $0.061 * *(2.58)$ \\
\hline INDUS & YES & YES & YES \\
\hline YEAR & YES & YES & YES \\
\hline Adj-R ${ }^{2}$ & 0.104 & 0.156 & 0.175 \\
\hline F-value & $6.56^{* * *}$ & $9.83^{* * *}$ & $11.09 * * *$ \\
\hline Mediating Effect & Boot SE & Boot LLCI & Boot ULCI \\
\hline-0.019 & 0.012 & -0.028 & -0.019 \\
\hline
\end{tabular}

Notes: ${ }^{*} \mathrm{p}<0.1,{ }^{* *} \mathrm{p}<0.05,{ }^{* * *} \mathrm{p}<0.01$.

Table 5. Test results of the mediating role of the NEID increment.

\begin{tabular}{|c|c|c|c|}
\hline Variables & $\triangle N E I D$ & $\Delta \% C O E_{i, t+1}$ & $\Delta \% C O E_{i, t+1}$ \\
\hline Constant & $-0.020(-1.56)$ & $-1.159 * * *(-3.94)$ & $-1.182 * * *(-3.91)$ \\
\hline PENALTY & $-0.22 * * *(-5.08)$ & $0.269 * * *(6.01)$ & $0.250 * * *(3.75)$ \\
\hline$\triangle N E I D$ & & & $-0.282 * *(-2.65)$ \\
\hline SIZE & $-0.004(-1.41)$ & $0.048 * * *(3.45)$ & $0.056 * * *(4.75)$ \\
\hline$L E V$ & $-0.002(-1.02)$ & $-0.133(-1.37)$ & $-0.136(-1.36)$ \\
\hline$R O A$ & $0.057 * *(1.86)$ & $0.113(0.45)$ & $0.131(0.43)$ \\
\hline GROW & $0.000(0.74)$ & $0.000(0.31)$ & $0.00(0.37)$ \\
\hline BETA & $0.012(0.13)$ & $0.075^{* * *}(4.53)$ & $0.075 * *(2.57)$ \\
\hline TURN & $-0.011(-0.98)$ & $-0.023(-0.94)$ & $-0.064(-0.56)$ \\
\hline$B M$ & $0.001(0.96)$ & $0.002(0.48)$ & $0.007(0.35)$ \\
\hline$G E P$ & $0.002 * * *(4.99)$ & $-0.022 * *(-2.37)$ & $-0.033 * * *(-3.75)$ \\
\hline PEP & $-0.004 * * *(-3.78)$ & $0.062 * *(2.69)$ & $0.063 * *(2.57)$ \\
\hline INDUS & YES & YES & YES \\
\hline YEAR & YES & YES & YES \\
\hline Adj-R ${ }^{2}$ & 0.097 & 0.156 & 0.159 \\
\hline F-value & $6.14 * * *$ & $9.83 * * *$ & $10.03 * * *$ \\
\hline
\end{tabular}


Table 5. Continued.

\begin{tabular}{|c|c|c|c|}
\hline Mediating Effect & Boot SE & Boot LLCI & Boot ULCI \\
\hline 0.062 & 0.012 & 0.017 & 0.029 \\
\hline
\end{tabular}

Notes: $* \mathrm{p}<0.1, * * \mathrm{p}<0.05, * * * \mathrm{p}<0.01$.

contain 0 , which indicates that the mediating effect of the NEID increment is significant.

The above results show that the penalty has a positive impact on PEID. The positive increment of PEID can reduce the positive effect between the penalty and COE. However, the penalty negatively affects NEID, and the negative NEID increment reduces the positive effect between the penalty and COE.

\section{Conclusions}

This paper studied the effect of the environmental administrative penalty on COE and tested the mediating role of the EID increment in this relationship.

First, it is found that the environmental administrative penalty can increase $\mathrm{COE}$ in the following year. The reason that investors demand a higher expected return may lie in that they consider firms with environmental penalties have a higher risk than the others.

Second, the EID increment plays a mediating role in the relationship between environmental administrative penalty and COE. Specifically, the negative increment of NEID can increase the effect between the penalty and COE, while the positive PEID increment can reduce the effect. This study shows that the penalty reduces NEID, which intensifies information asymmetry between investors and companies and increases the risk of estimating future returns and an increase in the expected return required by equity investors. However, the penalty increases positive disclosures, and then they reduce the information asymmetry between equity investors and companies, leading to a decrease in the risk of estimating future returns and decreasing equity investors' expected return.

These findings help us to understand the significance of environmental management to a firm's financing sustainability and enrich our cognition of the role of environmental disclosure. First, environmental penalties lead to higher equity costs in the following year. Thus, it can infer that compliance with environmental regulations helps the firm secure stable equity financing and avoid financing difficulties. Second, environmental disclosure increment plays a mediating role, which reflects that equity investors in Chinese have been able to distinguish the differences of corporate environmental disclosure in adjacent years. Actually, Chinese companies' management tends to take opportunistic actions, such as concealing or reducing some information to reduce the negative impact of environmental penalties on their companies. However, the reduced disclosures increase the financing cost in the following year. Therefore, after being penalized, the most favorable strategy for corporate financing may be to improve environmental reporting. From the perspective of environmental governance, we also have two enlightenments. First, environmental administrative penalty harms equity financing. It will force firms to protect the environment and control pollution emissions not to be penalized again. Second, the environmental penalty can deter the firm's environmental illegal behavior by damaging the firm's equity financing, which also indicates that environmental administrative penalty can effectively control environmental pollution and curb environmental violations.

This research is subject to the constraint on the choice of samples. In future studies, the number of samples can be increased. Besides, environmental penalties also may affect the debt cost. So, what role does environmental disclosure plays in the processes? It needs further study.

\section{Acknowledgments}

We thank Professor Qu for her invaluable assistance in preparing the original manuscript.

\section{Conflict of Interest}

The authors declare no conflict of interest.

\section{References}

1. DING X., QU Y., SHAHZAD M. The impact of environmental administrative penalties on the disclosure of environmental information. Sustainability, 11 (20), 1, 2019.

2. MENG X.H., ZENG S.X., SHI J.J., QI G.Y., ZHANG Z.B. The relationship between corporate environmental performance and environmental disclosure: An empirical study in China. Journal of Environmental Management, 145, 357, 2014.

3. GHOUL E.S., GUEDHAMI O., KIM H., PARK K. Corporate Environmental Responsibility and the Cost of Capital: International Evidence. Journal of Business Ethics, 149 (2), 335, 2018.

4. KIM K.H., KIM M.C., QIAN C. Effects of Corporate Social Responsibility on Corporate Financial Performance: 
A Competitive-Action Perspective. Journal of Management, 44 (3), 1097, 2018.

5. JACKSON G., BARTOSCH J., AVETISYAN E., KINDERMAN D., KNUDSEN J.S. Mandatory Nonfinancial Disclosure and Its Influence on CSR: An International Comparison. Journal of Business Ethics, 162 (2), 323, 2020

6. CHEN Y.C., HUNG M., WANG Y. The effect of mandatory CSR disclosure on firm profitability and social externalities: Evidence from China. Journal of Accounting and Economics, 65 (1), 169, 2018.

7. DHALIWAL D.S., LI O.Z., TSANG A., YANG Y.G. Voluntary nonfinancial disclosure and the cost of equity capital: The initiation of corporate social responsibility reporting. The Accounting Review, 86 (1), 59, 2011.

8. REVERTE C. The Impact of Better Corporate Social Responsibility Disclosure on the Cost of Equity Capital. Corporate Social Responsibility and Environmental Management, 19 (5), 253, 2012.

9. PLUMLEE M., BROWN D., HAYES R.M., MARSHALL R.S. Voluntary environmental disclosure quality and firm value: Further evidence. Journal of Accounting and Public Policy, 34 (4), 336, 2015.

10. LI S., LIU C. Quality of Corporate Social Responsibility Disclosure and Cost of Equity Capital: Lessons from China. Emerging Markets Finance and Trade, 54 (11), 2472, 2018.

11. YAO S., LIANG H. Analyst following, environmental disclosure and cost of equity: Research based on industry classification. Sustainability, 11 (2), 300, 2019.

12. GARZÓN-JIMÉNEZ R., ZORIO-GRIMA A. Effects of Carbon Emissions, Environmental Disclosures and CSR Assurance on Cost of Equity in Emerging Markets. Sustainability, 13 (2), 696, 2021.

13. RAIMO N., DE NUCCIO E., GIAKOUMELOU A., PETRUZZELlA F., VITOLlA F. Non-financial information and cost of equity capital: an empirical analysis in the food and beverage industry. British Food Journal, 123 (1), 49, 2020.

14. HAJAWIYAH A., ADHARIANI D., DJAKMAN C. The sequential effect of CSR and COE: family ownership moderation. Social Responsibility Journal, 15 (7), 939, 2019.

15. ELLILI N.O.D. Environmental, social, and governance disclosure, ownership structure and cost of capital: Evidence from the UAE. Sustainability, 12 (18), 7706, 2020.

16. LI L., LIU Q., WANG J., HONG X. Carbon information disclosure, marketization, and cost of equity financing. International Journal of Environmental Research and Public Health, 16 (1), 150, 2019.

17. LI L., LIU Q., TANG D., XIONG J. Media reporting, carbon information disclosure, and the cost of equity financing: evidence from China. Environmental Science and Pollution Research, 24 (10), 9447, 2017.

18. BUI B., MOSES O., HOUQE M.N. Carbon disclosure, emission intensity and cost of equity capital: multi-country evidence. Accounting and Finance, 60, 47, 2020.

19. GERGED A.M., MATTHEWS L., ELHEDDAD M. Mandatory disclosure, greenhouse gas emissions and the cost of equity capital: UK evidence of a U-shaped relationship. Business Strategy and the Environment, 30 (2), 908, 2021.

20. FONSEKA M., RAJAPAKSE T., TIAN G.L. The Effects of Environmental Information Disclosure and Energy Types on the Cost of Equity: Evidence from the Energy Industry in China. Abacus, 55 (2), 362, 2019.
21. SHAD M.K., LAI F.W., SHAMIM A., MCSHANE M. The efficacy of sustainability reporting towards cost of debt and equity reduction. Environmental Science and Pollution Research, 27 (18), 22511, 2020.

22. DAHIYA M., SINGH S. The linkage between CSR and cost of equity: an Indian perspective. Sustainability Accounting, Management and Policy Journal, ahead-ofp(ahead-of-prin), 2020.

23. CLARKSON P.M., FANG X., LI Y., RICHARDSON G. The relevance of environmental disclosures: Are such disclosures incrementally informative? Journal of Accounting and Public Policy, 32 (5), 410, 2013.

24. CHAVA S. Environmental Externalities and Cost of Capital. Management Science, 60 (9), 2223, 2014.

25. LI Y., EDDIE I., LIU J. Carbon emissions and the cost of capital: Australian evidence. Review of Accounting and Finance, 13 (4), 400, 2014.

26. SONG C., HAN S.H. Stock Market Reaction to Corporate Crime: Evidence from South Korea. Journal of Business Ethics, 143 (2), 323, 2017.

27. GONG G., HUANG X., WU S., TIAN H., LI W. Punishment by Securities Regulators, Corporate Social Responsibility and the Cost of Debt. Journal of Business Ethics, 1, 2020.

28. CHEN Y., ZHU S., WANG Y. Corporate fraud and bank loans: Evidence from china. China Journal of Accounting Research, 4 (3), 155, 2011.

29. HA $\beta$ L.H., VERGAUWE S., ZHANG Z. State-ownership and bank loan contracting: evidence from corporate fraud. European Journal of Finance, 25 (6), 550, 2019.

30. FISHER I.N., HALL G.R. Risk and Corporate Rates of Return. The Quarterly Journal of Economics, 83 (1), 79, 1969.

31. SHARFMAN M.P., FERNANDO C.S. Environmental risk management and the cost of capital. Strategic Management Journal, 29 (6), 569, 2008.

32. BERRY-STÖLZLE T.R., XU J. Enterprise Risk Management and the Cost of Capital. Journal of Risk and Insurance, 85 (1), 159, 2018.

33. KIM Y.B., AN H.T., KIM J.D. The effect of carbon risk on the cost of equity capital. Journal of Cleaner Production, 93, 279, 2015.

34. LEMMA T.T., FEEDMAN M., MLILO M., PARK J.D. Corporate carbon risk, voluntary disclosure, and cost of capital: South African evidence. Business Strategy and the Environment, 28 (1), 111, 2018

35. WEBER O. Environmental Credit Risk Management in Banks and Financial Service Institutions. Business Strategy and the Environment, 21 (4), 248, 2012.

36. JUNG J., HERBOHN K., CLARKSON P. Carbon Risk, Carbon Risk Awareness and the Cost of Debt Financing. Journal of Business Ethics, 150 (4), 1151, 2018.

37. EGGINTON J.F., MCBRAYER G.A. Does it pay to be forthcoming? Evidence from CSR disclosure and equity market liquidity. Corporate Social Responsibility and Environmental Management, 26 (2), 396, 2019.

38. AERTS W., CORMIER D., MAGNAN M. Corporate environmental disclosure, financial markets and the media: An international perspective. Ecological Economics, 64 (3), 643, 2008.

39. HEALY P.M., HUTTON A.P., PALEPU K.G. Stock Performance and Intermediation Changes Surrounding Sustained Increases in Disclosure. Contemporary Accounting Research, 16 (3), 485, 1999.

40. MENG X.H., ZENG S.X., TAM C.M. From Voluntarism to Regulation: A Study on Ownership, Economic 
Performance and Corporate Environmental Information Disclosure in China. Journal of Business Ethics, 116 (1), 217, 2013.

41. YAO S., LI S. Distance and government resource allocation: from the perspective of environmental information disclosure policy change. Applied Economics, 50 (54), 5893, 2018.

42. BOTOSAN C.A., PLUMLEE M.A., WEN H. The Relation between Expected Returns, Realized Returns, and Firm Risk Characteristics. Contemporary Accounting Research, 28 (4), 1085, 2011.

43. EASTON P.D. PE Ratios, PEG Ratios, and Estimating the Implied Expected Rate of Return on Equity Capital. The Accounting Review, 79 (1), 73, 2004.

44. BECK A.C., CAMPBELL D., SHRIVES P.J. Content analysis in environmental reporting research: Enrichment and rehearsal of the method in a British - German context. The British Accounting Review, 42 (3), 207, 2010.

45. AL-TUWAIJRI S.A., CHRISTENSEN T.E., HUGHES K.E. The relations among environmental disclosure, environmental performance, and economic performance a simultaneous equations approach. Accounting, Organizations and Society, 29 (5), 447, 2004.

46. ZENG,S.X., XU X.D., DONG Z.Y., TAM V.W.Y. Towards corporate environmental information disclosure: An empirical study in China. Journal of Cleaner Production, 18 (12), 1142, 2010.

47. EDWARDS A., SCHWAB C., SHEVLIN T. Financial constraints and cash tax savings. Accounting Review, 91 (3), 859, 2016.

48. MACKINNON D.P., LOCKWOOD C.M., WILLIAMS J. Confidence limits for the indirect effect: Distribution of the product and resampling methods. Multivariate Behavioral Research, 39 (1), 99, 2004.

49. HAYES A.F., SCHARKOW M. The Relative Trustworthiness of Inferential Tests of the Indirect Effect in Statistical Mediation Analysis: Does Method Really Matter? Psychological Science, 24 (10), 1918, 2013. 